OPEN ACCESS

Edited by:

Martin F. Quaas,

Leipzig University, Germany

Reviewed by:

Jouni Paavola,

University of Leeds, United Kingdom

Thomas H. Beery,

Kristianstad University, Sweden

*Correspondence:

Julia Leventon

leventon.j@czechglobe.cz

Specialty section:

This article was submitted to

Conservation and Restoration

Ecology,

a section of the journa

Frontiers in Ecology and Evolution

Received: 24 September 2020

Accepted: 30 April 2021

Published: 04 June 2021

Citation:

Leventon J, Duşe IA and Horcea-Milcu A-I (2021) Leveraging Biodiversity Action From Plural Values:

Transformations of Governance

Systems. Front. Ecol. Evol. 9:609853.

doi: $10.3389 /$ fevo.2021.609853

\section{Leveraging Biodiversity Action From Plural Values: Transformations of Governance Systems}

\author{
Julia Leventon ${ }^{1 \star}$, Ioana A. Duşe ${ }^{2}$ and Andra-Ioana Horcea-Milcu \\ ${ }^{1}$ Global Change Research Institute of the Czech Academy of Sciences, Brno, Czechia, ${ }^{2}$ Faculty of Sustainability, Leuphana \\ University of Lüneburg, Lüneburg, Germany, ${ }^{3}$ Hungarian Department of Biology and Ecology, Babes-Bolyai University, \\ Cluj-Napoca, Romania
}

In this paper, we argue that leveraging plural values into action for biodiversity requires a focus on transforming the biodiversity governance system. We draw on Donella Meadows' concept of Leverage Points, which outlines the "depth" of intervention in order to shift a system toward sustainability. Engaging with deep leverage points (system intent and goals) is argued to lead to greater transformation than engaging with shallow leverage points (system design and materials). We outline how embracing plural values of biodiversity requires changes at deeper systems properties within governance systems to create space to reflect diversity in values and knowledge systems, and move away from a focus on commodification of nature's contributions to people. We point toward political and policy sciences to highlight frameworks and concepts for understanding governance system transformation. We conclude with a call for meaningful engagement with such sciences in ongoing research.

Keywords: leverage points, sustainability transformations, systems thinking, biodiversity, natures contribution to people, political science

\section{INTRODUCTION}

In this paper, we address how the recognition of plural values of biodiversity can be harnessed towards action on biodiversity. Values are a core topic in emerging research into biodiversity conservation and management, and cover a huge variety of disciplines and approaches. Values of biodiversity can be understood in three broad classes, of instrumental, intrinsic and relational (Chan et al., 2016). For example, the valuation of, and payment for, ecosystem services literature, often focusses on instrumental (and sometimes intrinsic) values (Chee, 2004; Ring et al., 2010). Recognizing such values, and accounting for them in decision making is a key route to protecting vulnerable biodiversity (Nature Editorial, 2021), and dominant policy discourses, such as ecosystem accounting reflect this (see e.g., Dasgupta, 2021). However, emerging narratives in IPBES (Intergovernmental Panel for Biodiversity and Ecosystem Services) and across science call for the recognition of plural values of biodiversity and ecosystem services (Martin Lopez, 2021; Pascual et al., 2021). Such plural values include relational values, moral values and held values, and recognizing their overlaps and interconnections (Chan et al., 2018). The introduction of the IPBES Nature's Contributions to People (NCP) is part of the same concern to highlight and support with scientific evidence the importance of nature for human well-being. The recent delineation of relational values is another milestone in striving to capture an ever more comprehensive array of WHY nature is valuable (Chan et al., 2018; Himes and Muraca, 2018). 
In this essay, we look towards our governance systems, and argue that acting on plural values for biodiversity will require deeper changes in our governance systems for biodiversity. Governance systems include policies, the politics of what we govern and why, and actors and their responsibilities to make and implement decisions over a resource (in this case, biodiversity) (Jentoft, 2007; Duit and Galaz, 2008). They are multi-level and multi-sectoral, engaging organizations and actors in a range of roles and responsibilities (and powers) to make and implement decisions. For biodiversity, these systems comprise actors and organizations engaged in explicit biodiversity policy setting and action, and how these actors and organizations interplay with those from other sectors such as agriculture, energy, recreation (e.g., Paavola et al., 2009; Jiren et al., 2018). Following from the failure to meet the Aichi targets, attention has shifted back to governance systems, to push for renewed targets and resources for biodiversity management at national and international levels (Díaz et al., 2019; Chan et al., 2020; Xu et al., 2021). Pascual et al. (2021) have recently argued that policy needs to recognize plural worldviews and values for biodiversity, and that the policy sphere needs to address the political structures that prevent policy from grappling with plurality. We, the authors, extend this argument to consider how this generates a challenge for the governance systems that create and implement policy, and outline that it will require deeper changes in these systems.

In order to consider these challenges to governance systems, we draw on the framework of Leverage Points (LPs). The LP framework (Meadows, 1999) considers how we can fundamentally change systems. Systems are seen as complex interactions and interdependencies between human and nonhuman "parts" (e.g., people, organizations, ecosystems). To transform systems, there are different depths of leverage point; shallow points create only small changes to the system, while deeper points create transformational change by addressing the root causes of unsustainability. Meadows outlines 12 LPs, or system properties where change can be affected. These can also be condensed into four (in increasing order of depth): (1) materials, (2) processes; (3) design; and (4) intent (Abson et al., 2017). In order to use the framework to think about systems change, it is necessary to consider what the system is, where to intervene, and how these interventions interact across connected systems (Leventon et al., 2021).

This paper is not the first to engage with LPs to consider biodiversity (see Díaz et al., 2018; Chan et al., 2020; Mattijssen et al., 2020). Nor are we the first to link values and LPs (see e.g., O’Brien, 2018; Horcea-Milcu et al., 2019; Bieling et al., 2020). However, these approaches tend to consider how to target values to shift social-ecological systems and people's relationships with nature. They focus either on the governance of transformation (how transformation initiatives are governed), or governance for transformation (how governance systems deliver transformation). We, the authors, add a third dimension by looking specifically at the transformation of governance; exploring how our governance systems need to transform if they are to manage biodiversity in a way that respects plural values. Clearly these three dimensions are intertwined. However, the distinction is useful in explaining the perspective from which researchers can choose to focus their attentions.
We, the authors, create our argument by first outlining governance system properties in relation to LPs (see section "Governance System Properties and Leverage Points"). Here, we highlight the nested, connected nature of governance systems, and the systems characteristics embodied therein. Next, we look into the work on plural values in biodiversity and ecosystem services research (see section "Necessary Transformations of Governance Systems for Acting on Plural Values"). We consider framings of plural values, and how they are being presented as pathways for fundamental transformation toward sustainability. Based on these framings, we demonstrate the necessary deeper transformations of the governance system, if plural values are to be incorporated into policy. We then turn, in section "Perspectives for Understanding Processes of Governance System Transformations," to framings from political and policy science to demonstrate how these fields may help the biodiversity community to understand processes of change in governance systems. Throughout the paper, we refer to examples of biodiversity conservation within the European Union. This is intended to make the arguments more tangible, but does not constrain their relevance to only this context.

In presenting this essay, we, the authors, hope to demonstrate the need and role for meaningful engagement with political science in understanding the challenges and processes of moving from valuation to action for biodiversity. We do this in two ways: (1) By arguing that policy and action based on plural values of biodiversity requires much deeper shifts in governance systems than policy alone; and (2) by demonstrating that better linking to political science perspectives will help the biodiversity community to understand these governance systems, and the ways in which systems change (or don't). Thus our call to engage with political science is with the intention of gaining greater understanding in how and why values are represented and acted on in governance. Implicit in this paper is the normative position that biodiversity needs to be conserved, and that governance change is necessary to do so. However, it is not our intention to provide a road map for how to change governance systems. Indeed, the extent to which researchers should be engaging in governance systems change is one that is fraught with question of ethics and the nature of democracy. The biodiversity community could learn much from sharing with the climate change community on these questions. In particular, they could consider if researchers have a mandate to act on their science (Gardner and Wordley, 2019; Green, 2021), and how democratic systems could meet the challenges of global change emergencies (e.g., Willis, 2020).

\section{GOVERNANCE SYSTEM PROPERTIES AND LEVERAGE POINTS}

Governance systems can, as any system, be characterized according to its system properties, such as (1) materials; (2) processes; (3) design; and (4) intent. This is easiest to do with a closely defined governance system, for example the system of actors and policies around the EU common agricultural policy (CAP). For example, critiques of the CAP look to its 
intent to argue that it will never deliver biodiversity or broader environmental goals whilst it remains focused on the goals of production (Marsden and Sonnino, 2008). We can also consider how the design of the biodiversity conservation measures match to the ecosystem (e.g., Leventon et al., 2019). At the shallow system properties, we can consider the processes of providing support, and the materials, or the way that subsidies are granted for biodiversity support. It becomes clear that adjusting materials (e.g., the amount a farmer is paid for a biodiversity measure) creates a less fundamental change than adjusting the system goals of agricultural production (see also Pe'er et al., 2019).

Governance systems engage actors from across multiple sectors in processes of politics, polity and policy at all implementation levels (see e.g., Piattoni, 2009), meaning that they are nested, connected and complex. In the CAP system, we can see that we also have national (country level) governance systems that may be differently aligned to the deeper system intent introduced within the EU system, or that introduces different designs and processes. For example, adoption of the CAP measures in Romania has so far ignored the very realities and the values of the local peasant agriculture (Fox, 2011; Câmpeanu and Fazey, 2014). Furthermore, CAP systems are embedded within, and are linked to, much bigger scale systems such as the European economic system, which incorporates the intents of neoliberalism, and the democratic system, which introduces values of participation and inclusion, and specific system designs to deliver that.

Governance systems include individuals as one of the layers nested within them. These actors are engaged in shaping, implementing, enforcing, and indeed changing this governance system. Individuals in a governance system hold sets of beliefs: deep core beliefs, policy core beliefs, and secondary aspects (Sabatier, 1987). Deep core beliefs are those that are fundamental normative assumptions about how the world should work, and underpin all policy areas (e.g., biodiversity and poverty alleviation), while constraining or influencing more specific beliefs at the next level (policy attitudes, instrumental values) (Peffley and Hurwitz, 1993; Sabatier and JenkinsSmith, 1993). The policy core beliefs relate to valuations about policy programs and include preferences about how the policy system within a given sector (e.g., biodiversity conservation) should be addressed in order to act on these deep core beliefs. These would thus be analogous to beliefs about how the system should be structured, what roles and responsibilities, and general principles this is based on. The secondary or instrumental aspects relate to how resources should be distributed to achieve these policy core beliefs - for example how funding should be spent, analogous to the shallowest LPs of materials.

\section{NECESSARY TRANSFORMATIONS OF GOVERNANCE SYSTEMS FOR ACTING ON PLURAL VALUES}

Different forms of value, their measurement, and the actions they demand require changes at different properties within the governance system. At the shallowest system properties, intrinsic values fit nicely into existing governance systems and broader economic paradigms. The logical endpoint of being able to articulate instrumental values is to be able to account for and manage them in decision making, e.g., through ecosystem accounting. This has long been the case through ecosystem service frameworks, and in approaches that seek to offset losses or pay for the provision of ES. The assumption is that by improving our valuation techniques, and assigning monetary value to services that were previously outside of the market, we can improve the way we allocate resources and make costeffective decisions. Indeed, CAP reforms tend toward shallow leverage points, refining subsidies paid for greening measures. In our (the authors') opinion, such monetary valuation of instrumental values without changing the broader, growthfocused logic of our economic system, is an exercise in increasing commodification of nature. It is expanding neoliberalism in an attempt to internalize externalities and continue within the paradigm of pursuing economic growth (Kosoy and Corbera, 2010). It does not challenge deeper system properties by, for example, questioning this neoliberal paradigm.

Expanding framings and conceptualizations of plural values leads to a need to consider other expressions of value within our decision-making systems, and challenges our governance systems to find ways to engage with the way we make decisions and live within nature. It demands shifts to the deeper governance system properties to ensure society can recognize a diversity of humannature relationships and culturally driven or indigenous ways of relating to nature (Díaz et al., 2015; Muradian and Pascual, 2018; Pascual et al., 2021). As we create frameworks to understand why values matter, we also create ways to understand and articulate what these values are, and their relative importance. In parallel to the heterogeneity of conceptualizations (Kenter et al., 2019), there has been an important widening in valuation methods, following the same rationale of embracing plurality and opening up decision-making to different knowledge systems (Cornell et al., 2013; Díaz-Reviriego et al., 2019). Socio-cultural valuation (Iniesta-Arandia et al., 2014), plural valuation (Zafra-Calvo et al., 2020), and integrated valuation (Jacobs et al., 2018) mark progress toward considering multiple tangible and especially intangible values in an attempt to account for the blind spots of each individual method and avoid the undervaluation of biodiversity and Natures Contributions to People. In particular, the NCP concept more explicitly incorporates valuation perspectives closer to local and indigenous knowledge systems (Díaz et al., 2018; Hill et al., 2020). Collectively, this implies that recognizing plural values requires shifts in the way that we govern for biodiversity; moving away from a reliance on market-based mechanisms (changing intent), toward creating space to hear indigenous voices (changing design), and facilitating diversity in social-ecological systems (design).

A good example would come from local food systems across "eastern" Europe, and the values, local knowledge, traditions and relationship to biodiversity that they embody (e.g., Jehlièka et al., 2020). These localized systems are broadly beneficial for biodiversity, eschew pesticides and machinery and add to landscape heterogeneity. They draw on people's complex and 
plural values of biodiversity and ecosystem services (HorceaMilcu et al., 2016; Riechers et al., 2021). However, to create governance that reflects these values requires a shift in the design of systems (e.g., CAP) that are currently fundamentally designed around large landowners and industrial agriculture (Toma et al., 2021). This has the unfortunate effect that it actually drives biodiversity loss in areas where small scale agriculture is being forced out (Mikulcak et al., 2015). Policy would need to shift to facilitate greater diversity in food systems to allow plurality of values.

In emerging values literature, there is divergence in how plural values are framed as pathways toward improved biodiversity outcomes. The first pathway points to finding ways within our governance systems to identify, acknowledge and act on plural values to create biodiversity outcomes. The understanding of values seems to capitalize on already existent sustainability values, such as solidarity or responsibility (Preiser et al., 2017) or on place-based values (Grenni et al., 2020). The second pathway points to decision makers, NGO's, change makers and even researchers engaging with changing people's values to intervene in the way they interact with their surrounding environment, and thus create improved biodiversity outcomes. Here, values can be considered as a way to intervene and mobilize transformation potential (see e.g., Díaz et al., 2019; Chan et al., 2020; Stålhammar, 2021). Both pathways require changes within bigger scale governance systems and their interconnections, as well as the individuals and smaller scale systems that are nested within them.

In the first pathway, recognizing plural values would require changes in the design and intent of bigger scale systems. Here, it is recognized that people hold, and express, plural values for the biodiversity they interact with. However, the broader governance systems do not manage to account for or protect these values. For example community-based initiatives are often referred to as a response to biodiversity loss, that allow communities to act on their own values and relationships with biodiversity. However, this framing ignores the underlying, much larger drivers of biodiversity loss from other governance sectors (e.g., agriculture, timber production, the extractives industry) (Skutsch and Turnhout, 2020). Instead, if values are to play a role in leveraging sustainability transformations, these broader processes that constrain or facilitate people acting on their values of biodiversity must be addressed. Those seeking to protect biodiversity need to recognize that local level projects exist within complex systems of interplay between policies, actors, and physical processes that shape and constrain our abilities to act according to our values. Thus, governance and policy need to address the institutional and systemic barriers that are blocking the expression of sustainability aligned values and instead enable them (Bieling et al., 2020; Scoones et al., 2020). In order to benefit from the transformation potential of plural values, the broader political, cultural, social and economic context and system intents that communities operate within need to be addressed (Thompson et al., 2020).

In the second pathway, working with plural values requires a reconsideration of how knowledge is created and acted upon for governance. The choice of methods employed to determine value shapes the outcome; if policymakers are looking to identify and value intrinsic values, they will only reveal intrinsic values, which then shape policy outcomes in way that is targeted only to intrinsic values. Valuation methodologies that address plural values include deliberative approaches (Lliso et al., 2020), co-creation and co-design of research (Mauser et al., 2013) and co-production of knowledge (Wyborn et al., 2019), sustainability scenario building (Raudsepp-Hearne et al., 2020) or visioning desirable futures (Wiek and Iwaniec, 2014). These are interventional approaches because they go beyond the sole purpose of producing knowledge. They hold transformative potential for those involved as researchers, practitioners, policy makers and community members (Burch et al., 2019). Cocreation processes like this can be employed as a first step for planning strategies and actions that acknowledge the diverse values and perceptions of actors in the system, rather than exclude voices with values that don't fit the current system logic (Pereira et al., 2018; Galafassi et al., 2018). Such co-creation also facilitates greater reflexivity of those conducting the valuation process and acting on the knowledge generating, prompting them to be explicit about which methodologies they use, and how this choice influences the values captured and therefore reflected in policy making. To this end, the challenge to governance systems is to create spaces, including time and resources, to facilitate such co-created, reflexive knowledge for policy creation, and to make the process transparent.

\section{PERSPECTIVES FOR UNDERSTANDING PROCESSES OF GOVERNANCE SYSTEM TRANSFORMATIONS}

Moving beyond instrumental values, and recognizing plural values of biodiversity and NCP in policy requires creating change at deeper LPs of system design and intent, throughout the governance system. Embracing plurality through governance system transformation can manifest in facilitating locally meaningful governance arrangements, incorporating plural knowledge systems, and shifting the underlying system intent away from profit-generation. This is a challenge, and will not be met by purely focusing on eliciting, measuring and describing values (Stålhammar, 2021), nor by working predominantly at the community level, as has thus far been the case in the biodiversity values literature. Instead, we need to shift our focus on what people actually want to capture into decision-making, the diversity of perspectives on what needs to be addressed and governed, what the objectives of biodiversity conservation should be and what options exist for interventions to attain such objectives. It goes beyond policy, and beyond engaging with the existing system design by negotiating targets and allocating resources. Calls for setting policies and targets also need to recognize that the broader governance system, within the current biodiversity conservation paradigm, needs deeper transformation.

In order to understand how these necessary changes in the governance system happen (or don't), we need to engage 
with theories and understandings about how governance systems change, largely from political and policy science. This vast area of literature draws on e.g., theories of the policy process (see e.g., Weible and Sabatier, 2017), new institutionalism and path dependency (see e.g., Kern et al., 2015). These are frameworks for understanding what has been, not of designing and creating what could be. They are not ways of engaging in systems transformation; indeed careful questions would need to be asked about the democratic legitimacy of doing so. However, these theories offer insight into understanding why our governance systems look the way they do, and how they evolve and change. Explicitly bringing political science into our debates on values of biodiversity offers new skill sets, understandings and perspectives on how political and policy systems work and change, and around the governance system barriers to harnessing plural values for action on biodiversity.

Within this literature, learning from previous examples of governance systems undergoing wholescale shifts can demonstrate the barriers and pitfalls to such fundamental change. For example, Europeanisation work focusses on areas where countries must adopt and implement EU legislation (e.g., around the accession of new member states). Those member states for whom "downloading" the policy requires a significant shift in goals and structures are least likely to properly implement it (Börzel, 2002). In-depth research into the implementation of environmental policy in the newer member states confirms that a mismatch between the intent and ideas embedded within the EU policy, and that of the member states, is a cause of stalled implementation (Sotirov et al., 2015). Such work can help us beyond the EU, to understand the problematic implementation of biodiversity targets and policies (e.g., Hagerman and Pelai, 2016).

There is significant focus in implementation research on the role of structures in influencing policy change and implementation. Beyond whether or not the policy goals match, researchers focus on the degree of change that is required in structures to implement policies, and on the capacities available to make such changes (Carmin and Vandeveer, 2004). For example, in protected areas in the Czech Republic, Prazan et al. (2005) found that aligning the structures and policy instruments was a key to achieving policy goals. In Polish biodiversity conservation, such alignment is hampered by a lack of capacity, knowledge, and tools (Blicharska et al., 2011). While in other cases (see Yakusheva, 2019), the conservation management capacities are part of the historical and political development of the countries (particularly CEE countries), where policy change and implementation are largely shaped by lockedin elements of previous political regimes, often expressed in terms of path dependence (Radaelli, 2003; Bafoil, 2009). Thus, the degree of change required of the systems structures becomes a barrier to systems change; making more fundamental changes (i.e., to deeper leverage points, to recognize and incorporate plural values) more resisted.

A key element in creating acceptance for changing structures seems to actually lie in the beliefs that actors hold regarding what the structures should be (see policy core beliefs, in section
"Governance System Properties and Leverage Points"). Actors within the system hold values about how they should be working together, and how systems should be structured. When these beliefs clash with the structures introduced, this can be a barrier to implementation, and thus to change (see e.g., Leventon, 2015). Such beliefs can hinder systems change even where the actors agree with the overall beliefs embedded within system goals (the deep core beliefs and/or system intent). For example in exploring the acceptability of alternative governance structures to achieve biodiversity, actors could agree on the overall goal and purpose of working together, but resist moves toward collaborative management (Nieto-Romero et al., 2016; Velten et al., 2018). Much greater understanding of how core and policy beliefs are constructed, why they are held by governance actors, how they are manifested, and the influence they have on the governance system, is helpful in knowing where, who and how to engage.

\section{CONCLUSION: LEVERAGING PLURAL VALUES INTO ACTION BY TRANSFORMING GOVERNANCE SYSTEMS}

The challenge of drawing on plural values to create biodiversity outcomes will require deeper changes in the governance systems that create and implement biodiversity policy. As we move beyond purely instrumental values, we, as a society, need to make more fundamental changes to the way we govern. This includes creating spaces for diverse knowledge systems and human-nature relationships; we must facilitate different ways of working with communities to understand, elicit and transform values at the local level; and we must intervene in broader underlying systems that undermine recognizing plural values (e.g., the pursuit of profit in connected systems and underlying paradigms).

Making these changes means engaging with actors, structures and processes across the governance system, with the underlying system intent, the system design and structures so that diversity, inclusivity and plurality can be present in the mechanisms and policies we create. It requires us, the biodiversity community, to consider what a governance system looks like when it delivers policy that addresses plural values. We need to recognize that it's not just policy that needs to change, but the broader system that creates and delivers that policy; there is a broader governance system that needs transforming. If we are calling for recognition of plural values for action on biodiversity, we need to understand what this governance system is, and how it both persists and changes.

To address this challenge, we, the authors, encourage meaningful engagement with researchers from across policy and political sciences. Understandings generated in these disciplines allow us, the biodiversity community, to understand the beliefs held by governance actors, and how they are acted upon across different levels, and how they shape policies, practices and outcomes. Understandings of path dependency can help 
to explain why governance systems look the way they do, how they persist, and where there might be opportunities for change. And implementation research provides insight into how shifting structures without shifting intent may lead to flawed implementation, and thus not deliver policies and targets once they are created. Therefore, we, the authors, conclude with the suggestion that the biodiversity values research community engages with specialists within the political and policy sciences, even where their knowledge is not directly related to biodiversity, in order to explore how the governance system facilitates or hinders efforts toward creating action out of recognition of plural values.

\section{AUTHOR CONTRIBUTIONS}

$\mathrm{JL}$ conceived the idea for the manuscript and developed it in collaboration with A-IH-M and ID. JL led the writing of the manuscript. All authors contributed text and edited the manuscript.

\section{REFERENCES}

Abson, D. J., Fischer, J., Leventon, J., Newig, J., Schomerus, T., Vilsmaier, U., et al. (2017). Leverage points for sustainability transformation. Ambio 46, 30-39. doi: 10.1007/s13280-016-0800-y

Bafoil, F. (2009). Central and Eastern Europe: Europeanization and Social Change. New York: Palgrave MacMillan.

Bieling, C., Eser, U., and Plieninger, T. (2020). Towards a better understanding of values in sustainability transformations: ethical perspectives on landscape stewardship. Ecosyst. People 16, 188-196. doi: 10.1080/26395916.2020.1786165

Blicharska, M., Angelstam, P., Antonson, H., Elbakidze, M., and Axelsson, R. (2011). Road, forestry and regional planners' work for biodiversity conservation and public participation: a case study in Poland's hotspot regions. J. Environ. Plann. Manage. 54, 1373-1395. doi: 10.1080/09640568.2011.575297

Börzel, T. A. (2002). Member state responses to europeanization. J. Common. Market Stud. 40, 193-214. doi: 10.1111/1468-5965.00351

Burch, S., Gupta, A., Inoue, C. Y. A., Kalfagianni, A., Persson, Å, Gerlak, A. K., et al. (2019). New directions in earth system governance research. Earth Syst. Govern. 1:100006. doi: 10.1016/j.esg.2019.100006

Câmpeanu, C. N., and Fazey, I. (2014). Adaptation and pathways of change and response: a case study from Eastern Europe. Global Environ. Change 28, 351-367. doi: 10.1016/j.gloenvcha.2014.04.010

Carmin, J., and Vandeveer, S. D. (2004). Enlarging EU Environments: central and eastern europe from transition to accession. Environ. Polit. 13, 3-24. doi: $10.1080 / 09644010410001685119$

Chan, K. M. A., Balvanera, P., Benessaiah, K., Chapman, M., Díaz, S., GómezBaggethun, E., et al. (2016). Opinion: why protect nature? rethinking values and the environment. Proc. Natl. Acad. Sci. U S A. 113, 1462-1465. doi: 10.1073/ pnas. 1525002113

Chan, K. M. A., Boyd, D. R., Gould, R. K., Jetzkowitz, J., Liu, J., Muraca, B., et al. (2020). Levers and leverage points for pathways to sustainability. People Nat. 2, 693-717. doi: 10.1002/pan3.10124

Chan, K. M. A., Gould, R. K., and Pascual, U. (2018). Editorial overview: relational values: what are they, and what's the fuss about? Curr. Opin. Environ. Sustain. 35, A1-A7. doi: 10.1016/J.COSUST.2018.11.003

Chee, Y. E. (2004). An ecological perspective on the valuation of ecosystem services. Biol. Conserv. 120, 549-565. doi: 10.1016/j.biocon.2004.03.028

Cornell, S., Berkhout, F., Tuinstra, W., Tàbara, J. D., Jäger, J., Chabay, I., et al. (2013). Opening up knowledge systems for better responses to global environmental change. Environ. Sci. Policy 28, 60-70. doi: 10.1016/j.envsci. 2012.11.008

\section{FUNDING}

This research was funded by the Volkswagen Stiftung and the Niedersächsisches Ministerium für Wissenschaft und Kultur (Grant No. A112269). A-IH-M acknowledges European Union's Horizon 2020 Research and Innovation Programme through the Marie Sklodowska-Curie grant number 840207.

\section{ACKNOWLEDGMENTS}

The authors would like to thank Berta Martin-Lopez for her early contribution to launching the ideas that finally evolved into this manuscript. The authors also acknowledge and thank all project members for their ideas and input in the early stages of this work, even where they are not listed as authors. Full details of project members and their research are available at https: //leveragepoints.org A-IH-M acknowledges EU funding through the Marie Sklodowska-Curie grant number 840207.

Dasgupta, P. (2021). The Economics of Biodiversity: The Dasgupta Review. London: HM Treasury.

Díaz, S., Demissew, S., Carabias, J., Joly, C., Lonsdale, M., Ash, N., et al. (2015). The IPBES conceptual framework - connecting nature and people. Curr. Opin. Environ. Sustain. 14, 1-16. doi: 10.1016/j.cosust.2014.11.002

Díaz, S., Pascual, U., Stenseke, M., Martín-López, B., Watson, R. T., Molnár, Z., et al. (2018). Assessing nature's contributions to people. Science 359, 270-272. doi: 10.1126/science.aap8826

Díaz, S., Settele, J., Brondízio, E. S., Ngo, H. T., Agard, J., Arneth, A., et al. (2019). Pervasive human-driven decline of life on Earth points to the need for transformative change. Science 366:eaax3100. doi: 10.1126/science.aax 3100

Díaz-Reviriego, I., Turnhout, E., and Beck, S. (2019). Participation and inclusiveness in the Intergovernmental science-policy platform on biodiversity and ecosystem services. Nat. Sustain. 2, 457-464. doi: 10.1038/s41893-0190290-6

Duit, A., and Galaz, V. (2008). Governance and complexity emerging issues for governance theory. Governance 21, 311-335. doi: 10.1111/j.1468-0491.2008. 00402.x

Fox, K. (2011). Peasants into European farmers? EU integration in the Carpathian Mountains of Romania Freiburger sozialanthropologische Studien. Berlin: LIT Verlog, 33.

Galafassi, D., Daw, T. M., Thyresson, M., Rosendo, S., Chaigneau, T., Bandeira, S., et al. (2018). Stories in social-ecological knowledge cocreation. Ecol. Soc. 23:23. doi: 10.5751/ES-09932-230123

Gardner, C. J., and Wordley, C. F. (2019). Scientists must act on our own warnings to humanity. Nat. Ecol. Evol. 3, 1271-1272.

Green, A. J. K. (2021). Challenging conventions-a perspective from within and without. Front. Sustain. 2:662038. doi: 10.3389/frsus.2021.66 2038

Grenni, A., Soini, K., and Horlings, L. G. (2020). The inner dimension of sustainability transformation: how sense of place and values can support sustainable place-shaping. Sustain. Sci. 15, 411-422. doi: 10.1007/s11625-01900743-3

Hagerman, S. M., and Pelai, R. (2016). "As far as possible and as appropriate": implementing the Aichi Biodiversity Targets. Conserv. Lett. 9, 469-478.

Hill, R., Adem, Ç, Alangui, W. V., Molnár, Z., Aumeeruddy-Thomas, Y., Bridgewater, P., et al. (2020). Working with Indigenous, local and scientific knowledge in assessments of nature and nature's linkages with people. Curr. Opin. Environ. Sustain. 43, 8-20. doi: 10.1016/j.cosust.2019.12.006 
Himes, A., and Muraca, B. (2018). Relational values: the key to pluralistic valuation of ecosystem services. Curr. Opin. Environ. Sustain. 35, 1-7. doi: 10.1016/j. cosust.2018.09.005

Horcea-Milcu, A.-I., Abson, D. J., Apetrei, C. I., Duse, I. A., Freeth, R., Riechers, M., et al. (2019). Values in transformational sustainability science: four perspectives for change. Sustain. Sci. 14, 1425-1437. doi: 10.1007/s11625-019-00656-1

Horcea-Milcu, A.-I., Leventon, J., Hanspach, J., and Fischer, J. (2016). Disaggregated contributions of ecosystem services to human well-being: a case study from Eastern Europe. Reg. Environ. Change 16, 1779-1791. doi: 10.1007/ s10113-016-0926-2

Iniesta-Arandia, I., García-Llorente, M., Aguilera, P. A., Montes, C., and MartínLópez, B. (2014). Socio-cultural valuation of ecosystem services: uncovering the links between values, drivers of change, and human well-being. Ecol. Eco. 108, 36-48. doi: 10.1016/J.ECOLECON.2014.09.028

Jacobs, S., Martín-López, B., Barton, D. N., Dunford, R., Harrison, P. A., Kelemen, E., et al. (2018). The means determine the end - Pursuing integrated valuation in practice. Ecosyst. Ser. 29, 515-528. doi: 10.1016/j.ecoser.2017.07. 011

Jehlièka, P., Grîviòð, M., Visser, O., and Balázs, B. (2020). Thinking food like an East European: a critical reflection on the framing of food systems. J. Rural Stud. 76, 286-295. doi: 10.1016/j.jrurstud.2020.04.015

Jentoft, S. (2007). Limits of governability: institutional implications for fisheries and coastal governance. Mar. Policy 31, 360-370. doi: 10.1016/j.marpol.2006. 11.003

Jiren, T. S., Bergsten, A., Dorresteijn, I., Collier, N. F., Leventon, J., and Fischer, J. (2018). Integrating food security and biodiversity governance: a multi-level social network analysis in Ethiopia. Land Use Policy 78, 420-429. doi: 10.1016/ j.landusepol.2018.07.014

Kenter, J. O., Raymond, C. M., van Riper, C. J., Azzopardi, E., Brear, M. R., Calcagni, F., et al. (2019). Loving the mess: navigating diversity and conflict in social values for sustainability. Sustain. Sci. 14, 1439-1461. doi: 10.1007/s11625-01900726-4

Kern, F., Kuzemko, C., and Mitchell, C. (2015). "How and Why Do Policy Paradigms Change; and Does It Matter? The Case of UK Energy Policy," in Policy Paradigms in Theory and Practice, eds J. Hogan and M. Howlett (London: Palgrave Macmillan), 269-291.

Kosoy, N., and Corbera, E. (2010). Payments for ecosystem services as commodity fetishism. Ecol. Eco. 69, 1228-1236. doi: 10.1016/j.ecolecon.2009.11.002

Leventon, J. (2015). Explaining implementation deficits through multi-level governance in the EU's new member states: EU limits for arsenic in drinking water in Hungary. J. Environ. Plann. Manage. 58, 1137-1153. doi: 10.1080/ 09640568.2014.916611

Leventon, J., Abson, D. A., and Lang, D. J. (2021). Leverage points for sustainability transformations: nine guiding questions for sustainability science and practice. Sustain. Sci. 16, 721-726. doi: 10.1007/s11625-021-00961-8

Leventon, J., Schaal, T., Velten, S., Loos, J., Fischer, J., and Newig, J. (2019). Landscape-scale biodiversity governance: scenarios for reshaping spaces of governance. Env. Pol. Gov. 29, 170-184. doi: 10.1002/eet.1845

Lliso, B., Mariel, P., Pascual, U., and Engel, S. (2020). Increasing the credibility and salience of valuation through deliberation: lessons from the global south. Global Environ. Change 62:102065. doi: 10.1016/j.gloenvcha.2020.102065

Marsden, T., and Sonnino, R. (2008). Rural development and the regional state: denying multifunctional agriculture in the UK. J. Rural Stud. 24, 422-431. doi: 10.1016/j.jrurstud.2008.04.001

Martin Lopez, B. (2021). Plural valuation of nature matters for environmnetal sustainability and justice. London: The Royal Society.

Mattijssen, T. J. M., Ganzevoort, W., van den Born, R. J. G., Arts, B. J. M., Breman, B. C., Buijs, A. E., et al. (2020). Relational values of nature: leverage points for nature policy in Europe. Ecosyst. People 16, 402-410. doi: 10.1080/26395916. 2020.1848926

Mauser, W., Klepper, G., Rice, M., Schmalzbauer, B. S., Hackmann, H., Leemans, R., et al. (2013). Transdisciplinary global change research: the co-creation of knowledge for sustainability. Curr. Opin. Environ. Sustain. 5, 420-431. doi: 10.1016/j.cosust.2013.07.001

Meadows, D. (1999). Leverage Points: Places to Intervene in a System. Hartland: The Sustainability Institute.

Mikulcak, F., Haider, J. L., Abson, D. J., Newig, J., and Fischer, J. (2015). Applying a capitals approach to understand rural development traps: a case study from post-socialist Romania. Land Use Policy 43, 248-258. doi: 10.1016/j.landusepol. 2014.10.024

Muradian, R., and Pascual, U. (2018). A typology of elementary forms of humannature relations: a contribution to the valuation debate. Curr. Opin. Environ. Sustain. 35, 8-14. doi: 10.1016/j.cosust.2018.10.014

Nature Editorial. (2021). Growing support for valuing ecosystems will help conserve the planet. Nature 591:178. doi: 10.1038/d41586-021-00 616-9

Nieto-Romero, M., Milcu, A.-I., Leventon, J., Mikulcak, F., and Fischer, J. (2016). The role of scenarios in fostering collective action for sustainable development: Lessons from central Romania. Land Use Policy 50, 156-168. doi: 10.1016/j. landusepol.2015.09.013

O’Brien, K. (2018). Is the $1.5^{\circ} \mathrm{C}$ target possible? exploring the three spheres of transformation. Curr. Opin. Environ. Sustain. 31, 153-160. doi: 10.1016/j. cosust.2018.04.010

Paavola, J., Gouldson, A., and Kluvánková-Oravská, T. (2009). Interplay of actors, scales, frameworks and regimes in the governance of biodiversity. Env. Pol. Gov. 19, 148-158. doi: 10.1002/eet.505

Pascual, U., Adams, W. M., Díaz, S., Lele, S., Mace, G. M., and Turnhout, E. (2021). Biodiversity and the challenge of pluralism. Nat. Sustain. doi: 10.1038/s41893021-00694-7

Pe'er, G., Zinngrebe, Y., Moreira, F., Sirami, C., Schindler, S., Müller, R., et al. (2019). A greener path for the EU common agricultural policy. Science 365, 449-451. doi: 10.1126/science.aax3146

Peffley, M., and Hurwitz, J. (1993). Models of attitude constraint in foreign affairs. Polit. Behav. 15, 61-90. doi: 10.1007/BF00993417

Pereira, L. M., Karpouzoglou, T., Frantzeskaki, N., and Olsson, P. (2018). Designing transformative spaces for sustainability in social-ecological systems. Eco. Soc. 23:32. doi: 10.5751/ES-10607-230432

Piattoni, S. (2009). Multi-level governance: a historical and conceptual analysis. J. Eur. Integr. 31, 163-180. doi: 10.1080/07036330802642755

Prazan, J., Ratinger, T., and Krumalova, V. (2005). The evolution of nature conservation policy in the Czech Republic - challenges of Europeanisation in the white carpathians protected landscape area. Land Use Policy 22, 235-243. doi: 10.1016/j.landusepol.2003.09.010

Preiser, R., Pereira, L. M., and Biggs, R. (2017). Navigating alternative framings of human-environment interactions: Variations on the theme of 'Finding Nemo'. Anthropocene 20, 83-87. doi: 10.1016/j.ancene.2017.10.003

Radaelli, C. (2003). "The Europeanization of Public Policy," in The politics of Europeanization, eds K. Featherstone and C. Radaelli (Oxford: Oxford University Press).

Raudsepp-Hearne, C., Peterson, G. D., Bennett, E. M., Biggs, R., Norström, A. V., Pereira, L., et al. (2020). Seeds of good anthropocenes: developing sustainability scenarios for Northern Europe. Sustain Sci. 15, 605-617. doi: 10.1007/s11625019-00714-8

Riechers, M., Pătru-Duşe, I. A., and Balázsi, Á (2021). Leverage points to foster human-nature connectedness in cultural landscapes. Ambio 2021, $1-11$.

Ring, I., Hansjürgens, B., Elmqvist, T., Wittmer, H., and Sukhdev, P. (2010). Challenges in framing the economics of ecosystems and biodiversity: the TEEB initiative. Curr. Opin. Environ. Sustain. 2, 15-26. doi: 10.1016/j.cosust.2010.03. 005

Sabatier, P. A. (1987). Knowledge, policy-oriented learning, and policy change. Knowledge 8, 649-692. doi: 10.1177/0164025987008004005

Sabatier, P. A., and Jenkins-Smith, H. C. (1993). Policy change and learning: An advocacy coalition approach. Boulder CO: Westview Press.

Scoones, I., Stirling, A., Abrol, D., Atela, J., Charli-Joseph, L., Eakin, H., et al. (2020). Transformations to sustainability: combining structural, systemic and enabling approaches. Curr. Opin. Environ. Sustain. 42, 65-75. doi: 10.1016/j. cosust.2019.12.004

Skutsch, M., and Turnhout, E. (2020). REDD+: If communities are the solution, what is the problem? World Dev. 130:104942. doi: 10.1016/j.worlddev.2020. 104942

Sotirov, M., Lovric, M., and Winkel, G. (2015). Symbolic transformation of environmental governance: implementation of EU biodiversity policy in bulgaria and croatia between Europeanization and domestic politics. Environ. Plann. C Gov. Policy 33, 986-1004. doi: 10.1177/0263774X1560 5925 
Stålhammar, S. (2021). Assessing people's values of nature: where is the Link to Sustainability Transformations? Front. Ecol. Evol. 9:624084. doi: 10.3389/fevo. 2021.624084

Thompson, P. L., Guzman, L. M., Meester, L., Horváth, Z., Ptacnik, R., Vanschoenwinkel, B., et al. (2020). A process-based metacommunity framework linking local and regional scale community ecology. Ecol. lett. 23, 1314-1329. doi: $10.1111 /$ ele. 13568

Toma, I., Redman, M., Czekaj, M., Tyran, E., Grivins, M., and Sumane, S. (2021). Small-scale farming and food security - policy perspectives from central and eastern europe. Global Food Security 29:100504. doi: 10.1016/j.gfs.2021.10 0504

Velten, S., Schaal, T., Leventon, J., Hanspach, J., Fischer, J., and Newig, J. (2018). Rethinking biodiversity governance in European agricultural landscapes: Acceptability of alternative governance scenarios. Land Use Policy 77, 84-93. doi: 10.1016/j.landusepol.2018.05.032

Weible, C. M., and Sabatier, P. A. (2017). Theories of the policy process, Fourth Edn. Boulder, CO: Westview Press.

Wiek, A., and Iwaniec, D. (2014). Quality criteria for visions and visioning in sustainability science. Sustain Sci. 9, 497-512. doi: 10.1007/s11625-013-0208-6

Willis, R. (2020). Too Hot to Handle?: The Democratic Challenge of Climate Change. Bristol,ENG: Policy Press.

Wyborn, C., Datta, A., Montana, J., Ryan, M., Leith, P., Chaffin, B., et al. (2019). Co-Producing Sustainability: reordering the governance of science, policy, and practice. Annu. Rev. Environ. Resour. 44, 319-346. doi: 10.1146/annurevenviron-101718-033103

Xu, H., Cao, Y., Yu, D., Cao, M., He, Y., Gill, M., et al. (2021). Ensuring effective implementation of the post-2020 global biodiversity targets. Nat. Ecol. Evol. 5, 411-418. doi: 10.1038/s41559-020-01375-y

Yakusheva, N. (2019). Managing protected areas in central eastern europe: Between path-dependence and Europeanisation. Land Use Policy 87:104036. doi: 10. 1016/j.landusepol.2019.104036

Zafra-Calvo, N., Balvanera, P., Pascual, U., Merçon, J., Martín-López, B., van Noordwijk, M., et al. (2020). Plural valuation of nature for equity and sustainability: insights from the Global South. Global Environ. Change 63:102115. doi: 10.1016/j.gloenvcha.2020.102115

Conflict of Interest: The authors declare that the research was conducted in the absence of any commercial or financial relationships that could be construed as a potential conflict of interest.

Copyright (c) 2021 Leventon, Duşe and Horcea-Milcu. This is an open-access article distributed under the terms of the Creative Commons Attribution License (CC BY). The use, distribution or reproduction in other forums is permitted, provided the original author(s) and the copyright owner(s) are credited and that the original publication in this journal is cited, in accordance with accepted academic practice. No use, distribution or reproduction is permitted which does not comply with these terms. 